\section{THE UNCONSOIOUSNESS OF LIPSKI.}

\section{To the Editors of THE LANCET.}

SIRS,-As I gave evidence on the trial that the unconsciousness of Lipski might be caused by mental perturbation, and you have admitted to your columns some very strong remarks thereon, I trust, in fairness to me, you will admit this letter. The positive assertions of your correspondent in your issue of the 20th inst. (page 378) are mistakes, because Lipski in his confession says he fainted when he heard the people coming up the stairs. As to the abrasions on the elbows, about which so much has been said, they were caused by the mob seizing him by his bare arms, and trying to drag bim from the custody of the two policemen as they were taking him up Batty-street. The abrasions were not there when I found him under the bed. The police just managed to get him as far as my surgery, and took him in for safety. I pointed out to the police the abrasions that the crowd had made. In the interests of persons who, like Simon and Schmuss, in the future may be falsely accused of murder, I hope your correspondent will secure Lipski's case a place "in the records of forensic medicine," so that others may not, like him, seek "in vain for anything that would lend support to such a view" as I took.

Commercial-road, E., Aug. 24th, 1887.

\section{J. WILLIAM Kay.}

\section{SICILY.}

(From our Correspondent.)

THe Ga*setta Ufficiale puts it beyond question that in the general stampede from the cholera-stricken communes in this island not only the civil functionaries joined, but also, I regret to say, not a few medical practitioners and pharmacists. These deserters from their posts have each and all been subjected to severe marks of Government displeasure, professors having been deprived of their chairs and divisional surgeons of their appointments. As a foil, however, to this deplorable exhibition of moral cowardice, it is fair to mention that physicians and surgeons from all parts of the island and the peninsula have been besieging the Ministry of the Interior to obtain permission to serve in the cholerarisited localities, the majority of the applicants being young men eager to atone, even by their lives, for the defection of their demoralised brethren. Examples of the stuff of which these medical youths are made might easily be cited, and one of them, whose tragic end absolves me from the duty of withholding his name, I cannot refrain from mentioning. Vincenzo Rapisardo, Sicilian by birth and a medical student of fire years' standing, lost no time in enrolling himself among the volunteers in the cholera campaign. Catania was the place to which he was told off, and he worked night and day in relieving pationts and in helping forward the sanitary works. Mleanwhile the enemy had appeared in force at Paterno, his native village, where his family were still residing. Most of the functionaries of the place, civi as well as medical, had taken flight, when Rapisardo appeared on the scene. He at once took upon himself the Fork of half-a-dozen hands, visiting the sick, compounding medicines, performing every kind of hygienic duty, and keeping, by constant corrrespondence, the officials at headquarters cognisant of the morements of the disease. Day and night he laboured at his wellnigh solitary task, till he, too, was struck down by the malady, which his strength was ton far gone to resist. He died on the 5th inst., and a few days afterwards was followed to the grave by his mother and sister.

An assistant of Professor Bizzozero of Turin is another of these young medical heroes, and him, too, I may mention, as the Gorernment have made public recognition of his work. Dr. Canalis, whose name has before now appeared in your columns in connexion with certain departments of physiological research, received from Signor Crispi, then Minister of the Interior, now Premier of Italy, the mandate to go to Catania directly the cholera had declared itself. To Catania accordingly he went, and in concert with Signor Noghera, official inspector of sanitary works, he organised a thorough system of medical relief and hygienic precautions, exposing himself in a hundred different ways to the malady wherever it was most pronounced, and not leaving the spot until he had made return toit unnecessary. A friend who haslately seen him informs me that what Canalis found more disheartening than the stubbornness of the epidemic was the cowardice of thelocal authorities and the ignorance of the multitude. He has prepared, and is, I am told, about to publish, an official report ot his experiences, and he certainly will not spare those who have failed in their duty, or have been found wanting in common humanity. Moral paralysis is hardly the word for the inaction of the communal functionaries, who, according to Dr. Canalis, allowed from twenty to thirty cases a day to occur almost at their doors, and who were too frightened to inform themselves of the symptoms and to report the same to headquarters. And what is to be done with communes like many of which Dr. Canalis has just had experience? communes of 20,000 inhabitants, where the pigs patrol the streets and where the population threaten to rise en masse and stone the sanitary inspectors whodare toclose notoriously infected wells!

Serviue, whose commentary on Virgil contains so much information on the life of classical antiquity, tells us that at Massilia (the modern Marseilles), whenever a pestilence appeared, one of the poor offered himself to his fellowcitizens on these conditions; he was to be kept and daintily fed at the public expense for a whole year, and after that he was to be arrayed in verbena and sacrificial vestments and carried through the streets amid the execrations of the people-to make himself, as it were, the embodiment of all the maledictions of the townsfolk-by whom he was finally to be precipitated into the sea. This heathen custom, however, is intelligible and even rational, compared with the madness without method that assails Southern Italy in cholera times. At Risposta, in this island, the other day the countryfolk rose and murdered a man whom they suspected of secretly "propagating the malady." In other Sicilian localities the people openly accuse their priests of distributing "the poison," and post their names as worthy of assassination; and why? Because, amid the general sickness and mortality few or none of these spiritual men have been taken ill or died! On the 14th inst., shortly after midnight, the postal diligence plying between Caltagirone and Valsavoia, had reached a lonely township in the Commune of Granmichele, when it was suddenly stopped by twelve individuals armed with rifles. They presented their firearms at the windows, and commanded the coachman and the guard to deliver the post-bags at once. These they opened, removing the letters and newspapers and certain articles which find hospitality in the post-bags for the use of the military. They touched no other object of value, and even returned the guard his watch, which he had voluntarily given up to them. Mysterious brigands these! But it now appears that they were not gentlemen of the highway at all but honest countryfolk who thought they were doing a sanitary service by stopping the conveyance of cholerainfected correspondence between their own and the surrounding communes.

$\mathrm{Oh}$ for the day when, in the memorable words of Sir James Coxe, the late Scottish Commissioner in Lunacy, every citizen, not in Sicily only, but much nearer home, will be taught at school to be "the intelligent custodian of his own health." Southern Italy has more than her proper share of this educational leeway to make up, but now she is more likely to start fair in that wholesome direction than she has hitherto been - her leading stateman, Signor Crispi, himself the representative in the Italian Chamber of one of the divisions of this city, and now Prime Minister of the kingdom, being an enthusiastic sanitarian, one on whom the mantle of Bertani has worthily fallen, and who will make his term of office memorable by a vigorous carrying into effect of the new "Codice igienico." Under his auspices, reinforced, too, by his reassuring presence, Palermo has suffered but lightly from this return of her old enemy. The municipality, 1 may add, bave shown praiseworthy energy in seconding their distinguished townsman's initiative, and are at this moment organising depôts where good bread and sound meat can be sold to the very poor at prices within the reach of all. Palermo, Aug. 20th.

Ar an inquest recently held at Widnes on the body of a young man who died in consequence of injuries received in a game of football, the jury returned a verdict of accidental death. 